\title{
Development of Solar Power Operated Force Circulating Dryer
}

\author{
Ashish Kerketta, Suryakanta Khandai* and Chetan Singh \\ Department of Farm Machinery and Power Engineering, Sam Higginbottom University of \\ Agriculture, Technology and Sciences, Allahabad - 211007, (U.P.), India \\ *Corresponding author
}

\begin{tabular}{|l|}
\hline Ke y w o r d s \\
$\begin{array}{l}\text { Solar energy, Solar } \\
\text { dryer, Charge } \\
\text { controller, Battery, } \\
\text { Heating element, } \\
\text { Performance }\end{array}$ \\
\hline Article Info \\
\hline $\begin{array}{l}\text { Accepted: } \\
\text { 26 January } 2018 \\
\text { Available Online: } \\
\text { 10 February } 2018\end{array}$ \\
\hline
\end{tabular}

A B S T R A C T

In India $\mathrm{p}-\mathrm{v}$ cells or arrays are efficiently contributing in various sectors for power generation and lightning systems. Beside this it can also be used to make a system that operates on direct solar energy. Efforts are made to improve the efficiency of solar crop / potatoes dryer in the present work. The present model is consisting of photovoltaic cells, charge controller, battery, heating element or coil to improve the efficiency and specially modified for working in the night environment to dry crop, spices, potatoes, fruits and vegetables. In this dryer, the convection of heated air is forced due to difference in temperature. A domestic portable (mini) fan and heating element is used to improve the performance of solar power operated forced circulating dryer with the help of photovoltaic cell or solar panel. Existing solar dryer was modified by connecting solar collectors (1.955 $\mathrm{m} \times 0.53 \mathrm{~m})$. The dryer consist solar collector, battery, charge controller, frame, heating coil, fan, and cabinet. Frame was fabricated by L shaped angle iron having thickness 0.005 $\mathrm{m}$. Cabinet consists of tin sheet and thickness of tin was $0.0011 \mathrm{~m}$. The dimension of the cabinet was $0.95 \mathrm{~m} \times 0.56 \mathrm{~m} \times 0.39 \mathrm{~m}$ ( $1 \mathrm{x} \mathrm{w} \mathrm{x} \mathrm{d).} \mathrm{Modified} \mathrm{dryer} \mathrm{was} \mathrm{found} \mathrm{to} \mathrm{be} \mathrm{better}$ over open sun drying in respect of moisture evaporation, as they required lesser time.

\section{Introduction}

Drying is an excellent way to preserve food and solar dryers are appropriate food preservation technology for sustainable development. Drying was probably the first ever food preserving method used by man, even before cooking (Alamu et al., 2010). It involves the removal of moisture from agricultural produce so as to provide a product that can be safely stored for longer period of time. Open sun drying has been traditionally practiced in India which involves simply laying the agricultural products in the sun on mats, roofs or drying floors for drying agricultural products such as paddy, wheat, fish, fruits and vegetables but the products dried in the open sun often suffer from rain, wind-borne dirt and dust, infestation by insects, rodents and other animal. So the products may be seriously degraded to the extent that sometimes become inedible and the resulted loss of food quality in the dried products may have adverse economic effects on domestics and markets value. Some of the problems associated with open-air sun drying can be solved through the use of a solar dryer who comprises of collector, a drying chamber 
and sometimes a chimney (Madhlopa et al., 2002). Solar dryers have some advantages over sun drying when correctly designed. The solar dryer can be seen as one of the solutions to the world's food and energy crises. With drying, most agricultural produce can be preserved and this can be achieved more efficiently through the use of solar dryers. In comparison to natural "sun dries", solar dryers generate higher temperatures, lower relative humidity, and lower product moisture content and reduced spoilage during the drying process. They give faster drying rates by heating the air to 20 degree above ambient, which causes the air to move faster through the dryer, reduces its humidity and drying time is also significantly reduced.

In principle, air is heated by solar radiation and naturally circulated by pressure gradients which promote vertical airflow. Consequently, these dryers require no electrical or mechanical components because the natural convection driving force is based only on temperature difference or changes in air density. For these reasons, solar dryers are often considered more effective than sun drying with operating costs generally lower than mechanized dryers (Chen et al., 2009).

The solar drier can be classified basically into two types: natural convection type dryers and forced circulation type dryers. Natural convection dryers do not require a fan to pump the air through the dryer. The low air flow rate and the long drying time, however, result in low drying capacity. Where large quantities of fresh produce are to be processed for the commercial market, forced convection dryers should be used. Solar cabinet-and box type driers are used to dry small quantities of food or vegetables. They are easily built out of locally available materials and using semiskilled labor. This solar drying system will consist of two parts solar collector and solar drying cabinet. Solar collector with area of
1.46 sq. $m$ and cabinet with area of 0.17 sq. $\mathrm{m}$. Food scientists have found that by reducing the moisture content of food to 10 to $20 \%$, bacteria, yeast, mold and enzymes are all prevented from spoiling it (Gallali, et al., 2000). Microorganisms are effectively killed when the internal temperature of food reaches $145^{\circ} \mathrm{F}$. The flavor and most of the nutritional value of dried food is preserved and concentrated. Dried foods do not require any special storage equipment and are easy to transport (Waewsak et al., 2006).

Fabricated and tested for the solar chimney dryer, the vapour formed due to evaporation, is taken away by the air entering into the drying chamber from one end and escapes through the chimney provided at the top with the aid of the supplied DC fan, while for the solar cabinet dryer, the vapour escapes through hole provided at the side of the system. It was finally observed that solar chimney dryer yields the best result. The colour and the flavour of the food stuffs dried with this dryer are comparable to that of a high quality dried in markets. They are free from microbiological contamination (Medugu, 2010).

Most of the agricultural products are dried at temperature range of 45 to 75 degree Celsius. Solar energy is promising option for generating hot air of this temperature ranges for drying agricultural produces. This experiment presents with objective on developments of modified forced circulating solar dryer technologies for drying of potato slice. Previous efforts on solar drying of potato slice are critically examined.

\section{Materials and Methods}

The experiments were carried out at FMP lab VIAET, SHUATS Allahabad (N 25.41414 ${ }^{\circ} \mathrm{E}$ $\left.81.84876^{\circ}\right)$. To design the improved solar drier materials are required as follows: 


\section{Fabrication}

A photovoltaic (p v) modules is a packaged connect assembly of 60 photovoltaic cells photovoltaic modules constitute the photovoltaic array of a photovoltaic system that generates and supplies solar electricity in commercial and residential application. Each modules is rated by its DC output power under standard test(SDT), and typically ranges from 100 to 365 watts (W).In this experiment 250 watts solar modules is used and it gives 10 ampere per hour current. Rated peak power (P $\max ) 250 \mathrm{~W}$, Rated voltage (V mp) $34.85 \mathrm{~V}$, Rated current (I mp) 10A, short circuit current (I sc) $11.25 \mathrm{~A}$.

Frame was fabricated by $\mathrm{L}$ shaped angle iron having thickness $0.005 \mathrm{~m}$ for placing the solar collector in 65 degree from the horizontal (depends on latitude and longitude of that particular area to absorb maximum solar radiation) \& drying chamber in 90 degree from the horizontal (for effective forced circulation of air). The dimension of frame was $1.95 \mathrm{~m} \times 0.99 \mathrm{~m}$. Cabinet consists of tin sheet and thickness of tin was $0.0011 \mathrm{~m}$.

The dimension of the cabinet was $0.86 \mathrm{~m} \mathrm{x}$ $0.56 \mathrm{~m} \times 0.39 \mathrm{~m}(1 \mathrm{x}$ w x d). Heating coil heated air is passed through two removable trays each of size $0.53 \mathrm{~m}$ length $\mathrm{x} 0.36 \mathrm{~m}$ wide in equidistance of total height of the drying chamber and made of wire mesh framed on which the drying product is spread. The trays are inserted and removed through the door provided in the back of the cabinet. To increase air circulation rates blower have been placed on the bottom of the dryer chamber.

A charge controller regulator or battery regulator limits the rate at which electric current is added to or drawn from electric batteries. It prevents overcharging and may protect against over voltage, which can reduce battery performance or lifespan, and may pose a safety risk. In this experiment 10 amp charge controller is used. An electric battery is a device consisting of one or more electrochemical cells with external connection provided to power electrical devices. The terminal marked negative source of electrons that connected to an external circuit will flow and deliver energy to an external device. In this experiment dry battery is used, battery capacity is 90 ampere per hour 12 volt and 1079 watts.

A blower is a machine it is used to create flow within a fluid, typically a gas such as air, In this experiment 12 volt 6 watts DC fan is used and in this fan regulator is provide for control the air flow velocity of fan. A heating coil or element convert electricity into heat through process of ohmic heating. In this experiment 12 volt 350 watts heating element is used for heating the drying chamber. It took 29.33 ampere current and it generates $70 \mathrm{c}$ temperature.

\section{Estimating the cost of solar power operated forced circulating dryer}

The cost of operation of solar dryer is divided under two heads as fixed cost and operating cost.

\section{Fixed cost}

Depreciation - It is the loss of value of a machine with the passing of time.

$$
\mathrm{D}=\frac{\mathrm{C}-\mathrm{S}}{\mathrm{LXH}}(3.4)
$$

Where,

$$
\begin{aligned}
& D=\text { depreciation per hour } \\
& C=\text { capital investment } \\
& S=\text { salvage value, } 10 \% \text { of capital }(C / 10) \\
& H=\text { number of working hours per year } \\
& \mathrm{L}=\text { life of machine in years. }
\end{aligned}
$$


Interest - Interest is calculated on the average investment of the machine taking into consideration the value of the machine in first and last year.

$\mathrm{I}=\frac{\boldsymbol{C}+\boldsymbol{S}}{\mathbf{2}} \times \frac{\mathrm{i}}{\mathrm{H}}(3.5)$

Where,

$\mathrm{I}=$ interest per hour

$\mathrm{i}=\%$ rate of interest per year.

$=$ Assume $10 \%$ per year.

Housing - It is calculated on the basis of the prevailing rate of the locality but roughly speaking, the housing cost may be taken as $1 \%$ of the initial cost of the machine per year.

@ $1 \%$ of the initial cost of the machine

Insurance - It is taken on the basis of the actual payment to the insurance company but roughly speaking, the housing cost may be taken as $1 \%$ of the initial cost of the machine per year.

It is taken as $1 \%$ of the initial cost of the machine per year.

Taxes - Taxes are calculated on the basis of the actual taxes paid per year but roughly speaking, it may be taken as $1 \%$ of the initial cost of the machine per year.

@ $1 \%$ of the initial cost of the machine

\section{Operating cost}

Lubricants- Charges for lubricants should calculate on the basis of actual fuel consumption, but roughly speaking, the lubricants cost varies between 30 to $35 \%$ of the fuel cost.

Lubricants $=0$ Rs.
Repairs and maintenance of battery-Cost of repair and maintenance vary between 5 to $10 \%$ of the initial cost of the machine per year.

Wages- Wages are calculated on the basis of actual wages of the workers.

(Assume wage of operator per day Rs. 250/-)

\section{Results and Discussion}

The results of the experiments for determining the performance of modified forced circulating solar dryer with open sun drying are presented and discussed in this chapter. Experimental data have been analyzed, presented and interpreted logically in the theories. For analysis and presentation of data, computer software was used to have a better understanding. The results have been discussed, inferences have been drawn and possible reasons have been discussed.

The weather throughout the experiments was cloudy at day time. The maximum ambient temperature reached $34^{\circ} \mathrm{C}$ at 2:00 PM around noon.

Average weather report in Allahabad, The average relative humidity of the ambient air was $88.48 \%$, Minimum and Maximum wind speed was 5 to $10 \mathrm{~km} / \mathrm{h}$ during the experiment time.

\section{Specification of modified forced circulating solar dryer}

Existing solar dryer was modified by connecting solar collectors $(1.955 \mathrm{~m} \mathrm{x} 0.53$ $\mathrm{m})$. The dryer consist solar collector, battery, charge controller, frame, heating coil, fan, and cabinet. Frame was fabricated by L shaped angle iron having thickness $0.005 \mathrm{~m}$. Cabinet consists of tin sheet and thickness of tin was $0.0011 \mathrm{~m}$. The dimension of the cabinet was $0.95 \mathrm{~m} \times 0.56 \mathrm{~m} \times 0.39 \mathrm{~m}$ ( $1 \mathrm{x}$ w x d). 


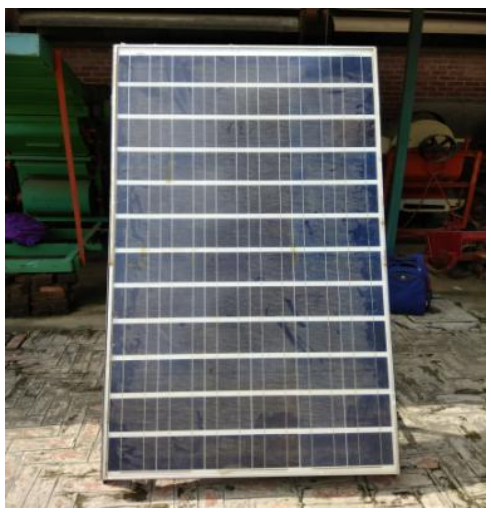

Solar collector
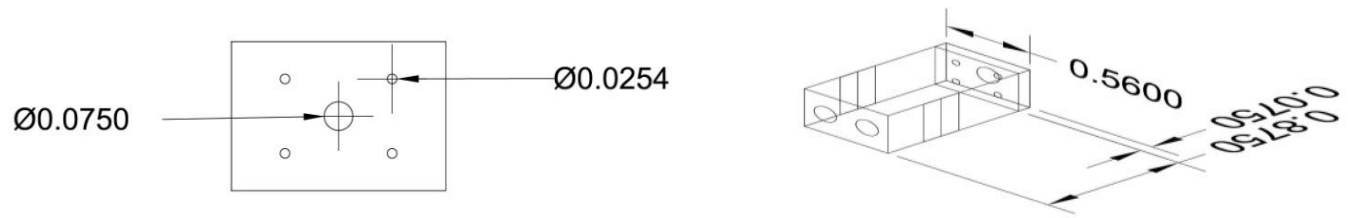

2D diagram of cabinet

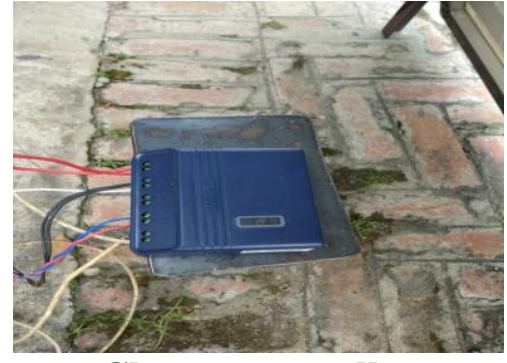

Charge controller

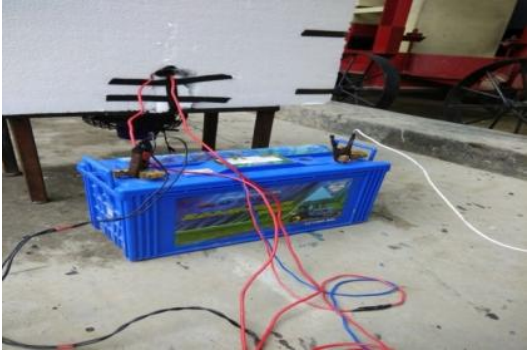

Battery

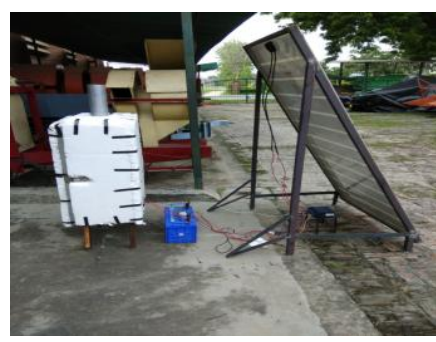

Modified Solar Dryer

Blower

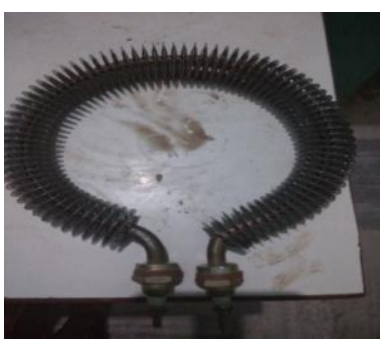

Heating coil

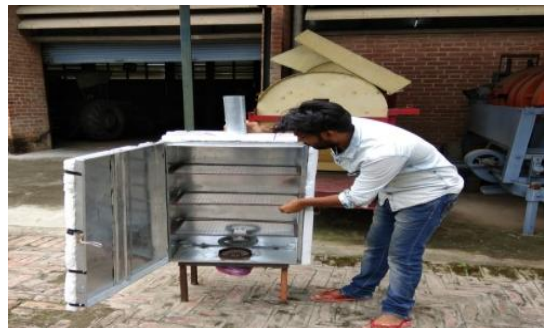

Solar collector

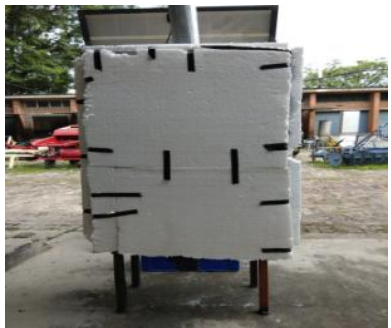

Cabinet

Arranging and provide insulation in cabinet 
Table.1 Specification of modified forced circulating solar dryer

\begin{tabular}{|l|c|}
\hline \multicolumn{1}{|c|}{ Dimensions of Cabinet } & \\
\hline Box height & $0.95 \mathrm{~m}$ \\
\hline Box width & $0.56 \mathrm{~m}$ \\
\hline Box length & $0.39 \mathrm{~m}$ \\
\hline Base hole diameter & $0.075 \mathrm{~m}$ \\
\hline Upper hole diameter & $0.025 \mathrm{~m}$ \\
\hline Tin thickness & $0.0011 \mathrm{~m}$ \\
\hline Total length of wire & $10 \mathrm{~m}$ \\
\hline Width of wire mash plat & $0.36 \mathrm{~m}$ \\
\hline Length of wire mash plat & $0.53 \mathrm{~m}$ \\
\hline \multicolumn{1}{|c|}{ Dimensions of solar panel } \\
\hline Solar module height & \\
\hline Solar module width & $0.99 \mathrm{~m}$ \\
\hline Solar module thickness & $0.53 \mathrm{~m}$ \\
\hline & $0.05 \mathrm{~m}$ \\
\hline \multicolumn{1}{|c|}{ Dimensions of frame } \\
\hline Frame width & \\
\hline Frame length & $0.99 \mathrm{~m}$ \\
\hline Ground Clearance back side & $1.955 \mathrm{~m}$ \\
\hline Ground Clearance back front & $0.71 \mathrm{~m}$ \\
\hline Frame Inclination Angle & $0.71 \mathrm{~m}$ \\
\hline
\end{tabular}

The experiments were carried out at FMP lab VIAET, SHUATS Allahabad (N 25.41414 ${ }^{\circ}{\mathrm{E} 81.84876^{\circ}}^{\circ}$

\begin{tabular}{|c|l|c|}
\hline S. N. & Name of Material & Quantity \\
\hline $\mathbf{1}$ & Solar panel & 1 \\
\hline $\mathbf{2}$ & Frame & 2 \\
\hline $\mathbf{3}$ & Charge controller & 1 \\
\hline $\mathbf{4}$ & Knife & 1 \\
\hline $\mathbf{5}$ & Battery & 1 \\
\hline $\mathbf{6}$ & Wire & 1 \\
\hline $\mathbf{7}$ & Fan & 1 \\
\hline $\mathbf{8}$ & Heating coil & 2 \\
\hline $\mathbf{9}$ & Thermocool & 8 \\
\hline $\mathbf{1 0}$ & Tin Box & 1 \\
\hline $\mathbf{1 1}$ & Wiring tape & 2 \\
\hline $\mathbf{1 2}$ & Wire mesh plate & 3 \\
\hline $\mathbf{1 3}$ & Mseal & 12 \\
\hline $\mathbf{1 4}$ & Power plug & 1 \\
\hline
\end{tabular}


Estimating the cost of solar power operated forced circulating dryer

Depreciation

$$
\mathrm{D}=\frac{27972 X 010}{4 X 500}=1.3986 \mathrm{Rs}
$$

Interest cost

$I=\frac{27972+(27972 \times 0.10)}{2} \times \frac{10}{100 \times 1000}=$ 2.7972Rs.

\section{Housing cost}

Housing cost $/$ hour $=\frac{27972 \times 1}{1000 \times 100}=0.27972 \mathrm{Rs}$

\section{Insurance cost}

Insurance $=\frac{27972 \times 1}{1000 \times 100}=0.27972$ Rs.

\section{Taxes cost}

Taxes $=\frac{27972 \times 1}{1000 \times 100}=0.27972$ Rs.

\section{Operating costs}

Repairs and maintenance- $-\frac{27972 \times 6}{100 \times 1000}=1.67832$ Rs

Wages-Wages of operator/hr $@ \frac{250}{8}=31.25 \mathrm{Rs}$

\section{Fixed cost}

Depreciation $(\mathrm{D})=1.3986$ Rs.

Interest $(\mathrm{I})=2.7972 \mathrm{Rs}$

Housing $=0.27972$ Rs

Insurance $=0.27972 \mathrm{Rs}$

Taxes $=0.27972 \mathrm{Rs}$
Total Fixed cost = $1.3986+2.7972+0.27972+0.27972+0.27972=$ 5.03496 Rs.

\section{Operating Cost}

Fuel cost $=0$ Rs.

Lubricants $=0$ Rs.

Repairs and maintenance $=1.67832 \mathrm{Rs}$.

Wages $=31.25$ Rs .

Total Operating cost $=0+0+1.67832+31.25=$ 32.928 Rs.

Total cost of solar dryer/hr $=$ Fixed cost +Operating Cost

$=5.03496+32.92832=37.963$ Rs. Or $=$ Rs .37

In this cases the use of hot air drying leads to considerable reduction of drying time in comparison to sun drying and the quality of the product dried in the hot air oven was of better quality dried products as compared to sun dried products.

From the above studies the following results were obtained:

Solar dryer was modified by connecting solar collectors (1.955 m x $0.53 \mathrm{~m})$.

The dryer consist solar collector, battery, charge controller, frame, heating coil, fan, and cabinet. Frame was fabricated by L shaped angle iron having thickness $0.005 \mathrm{~m}$. Cabinet consists of tin sheet and thickness of tin was $0.0011 \mathrm{~m}$. The dimension of the cabinet was $0.95 \mathrm{~m} \times 0.56 \mathrm{~m} \times 0.39 \mathrm{~m}(1 \mathrm{x} \times \mathrm{x} \mathrm{d})$.

The time taken under hot air oven drying was less in comparison to sun drying.

Highest drying rate was achieved with hot air oven drying $70^{\circ} \mathrm{C}$ followed by hot air oven $60^{\circ} \mathrm{C}$, open sun dryingand hot air oven $50^{\circ} \mathrm{C}$. 


\section{References}

Chen, C. R., Sharma, A., and Vu Lan, N. 2009. Solar-energy drying systems: A review. Renewable and Sustainable Energy Reviews, 13, 1185-1210.

Gallali Y. M, Abujnah, Y.S. and Bannani, F.K. 2000. Preservation of fruits and vegetables using solar drier: a comparative study of natural and solar drying, III; chemical analysis and sensory evaluation data of the dried samples (grapes, ®gs, tomatoes and onions), Renewable Energy 19 (2000)
$203 \pm 212$

Madhlopa, A., Jones, V. J. and Saka, D.K., 2002. A solar air heater with composite absorber systems for food dehydration, Renewable Energy 27 (2002) 27-37.

Medugu, D. W. 2010. Performance study of two designs of solar dryers. Department of Physics, Adamawa state University, Mubi, Nigeria.

Waewsak, J., Chindaruksa, S., and Punlek, C. 2006. A mathematical modeling study of hot air drying for some agricultural products. Thammasat Intenational Journal of Science 11(1):14-20.

\section{How to cite this article:}

Ashish Kerketta, Suryakanta Khandai and Chetan Singh. 2018. Development of Solar Power Operated Force Circulating Dryer. Int.J.Curr.Microbiol.App.Sci. 7(02): 3071-3078. doi: https://doi.org/10.20546/ijcmas.2018.702.370 